\title{
Zasada sprawnej egzekucji sądowej jako element efektywnego wymiaru sprawiedliwości
}

\section{Wprowadzenie}

$Z$ asada efektywnej ochrony sądowej (prawnej) stanowi element unijnego porządku prawnego, systemu konwencyjnego, a także występuje w systemach krajowych ${ }^{1}$. Wskazuje się w literaturze przedmiotu, iż pojęcie efektywnej ochrony sądowej w prawie Unii Europejskiej oraz zasady efektywności zostało wykształcone oraz jest stale precyzowane co do samej koncepcji oraz jej konturów przez orzecznictwo Trybunału Sprawiedliwości Unii Europejskiej². Pojęcie efektywnej ochrony prawnej obejmuje ochronę na poziomie sądowym oraz pozasądowym.

Podstawowym elementem skutecznej ochrony prawnej jest prawo do sądu, wyrażone w art. 47 zd. 1 Karty Praw Podstawowych Unii Europejskiej ${ }^{3}$ oraz art. 6 ust. 1 Konwencji o Ochronie Praw Człowieka i Podstawowych Wolności ${ }^{4}$. Sku-

\footnotetext{
* Dr Joanna Derlatka - adiunkt w Zakładzie Prawa Gospodarczego i Finansowego, Wydział Prawa, Administracji i Zarządzania UJK w Kielcach; e-mail: joanna.derlatka@ujk.kielce.pl.

${ }^{1}$ Z. Kmieciak, Efektywność sądowej kontroli administracji publicznej, $\mathrm{PiP}$ 2010, nr 11, s. 21.

2 A. Wróbel, Autonomia proceduralna państw członkowskich. Zasada efektywności oraz efektywnej ochrony sądowej w prawie Unii Europejskiej, Ruch Prawniczy, Ekonomiczny i Socjologiczny 2005, tom VXII, z. 1, s. 35.

${ }^{3}$ Dz.Urz. UE C Nr 326, s. 391. Zgodnie z art. 47 zd. 1 Karty Praw Podstawowych UE: „Każdy, kogo prawa i wolności zagwarantowane przez prawo Unii zostały naruszone, ma prawo do skutecznego środka prawnego przed sądem, zgodnie z warunkami przewidzianymi w niniejszym artykule" - tekst dokumentu dostępny jest na stronie internetowej: http://oide.sejm.gov.pl/oide/?option=com_con tent\&view=article\&id=14428\&Itemid=422 [dostęp: 11.04.2017].

${ }^{4}$ Konwencja o Ochronie Praw Człowieka i Podstawowych Wolności sporządzona w Rzymie dnia 4 listopada 1950 r., zmieniona następnie Protokołami nr 3, 5 i 8 oraz uzupełniona Protokołem nr 2, Dz.U. z 1993 r. Nr 61, poz. 284; dalej jako EKPC albo Konwencja.
} 
teczna ochrona prawna jest natomiast wymogiem szerszej zasady efektywności, rozumianej jako zasada systemowa oraz aksjologiczna ${ }^{5}$. W poniższych uwagach, analizie poddany zostanie ten element prawa do sądu, który sprawia, iż prawo to nabiera charakteru realnego, a mianowicie prawo do żądania wykonania prawomocnego orzeczenia sądu w drodze egzekucji. Doniosłość znaczenia egzekucji dla efektywnej ochrony prawnej wymaga podkreślenia. Jest ona także dostrzegana w doktrynie. H. F. Gaul wskazał, iż postępowanie rozpoznawcze stanowi jedynie tzw. „fazę wstępną”, zaś dopiero egzekucja służy właściwej realizacji efektywnej ochrony sądowej ${ }^{6}$.

Zasada sprawnej egzekucji, która stanowi istotę prawa do sądu, zostanie poddana analizie za pomocą metody dogmatycznej, wymagającej oceny polskich mechanizmów procesowych służących jej realizacji, a także metody komparatystycznej w odniesieniu do systemu konwencyjnego. Przyjęcie za przedmiot analizy zasady sprawnej egzekucji sądowej w kontekście EKPC wymaga przytoczenia stosownych wywodów poczynionych przez Trybunał w Strasburgu. Celowo pomięte zostaną rozważania nad efektywnością wymiaru sprawiedliwości w kontekście orzecznictwa Trybunału Sprawiedliwości Unii Europejskiej ${ }^{7}$. Można jedynie zatrzymać się na określeniu desygnatów wspólnotowego pojęcia „efektywnego środka prawnego" (effecitive remedy). A. Wróbel uznał, iż prawo do efektywnego środka prawnego oznacza w istocie prawo do efektywnej ochrony sądowej, co uzasadnia objęcie zakresem znaczeniowym pojęcia efektywnego środka prawnego nie tylko roszczenia odszkodowawczego, lecz również postępowania sądowego z jego instytucjami procesowymi ${ }^{8}$. Uwaga ta jest na tyle istotna, iż skłania do wniosku, by prawo do sprawnej egzekucji sądowej zaliczyć do desygnatów wspólnotowego pojęcia „efektywnego środka prawnego" na gruncie prawa wspólnotowego.

Punktem wyjścia niniejszych rozważań będzie teza, iż postępowanie egzekucyjne służy zaspokojeniu roszczeń wierzyciela, których nie udało mu się

${ }^{5}$ N. Półtorak (w:) System Prawa Administracyjnego. Tom 3. Europeizacja prawa administracyjnego, red. R. Hauser, A. Wróbel, Z. Niewiadomski, Warszawa 2014, s. 191-193.

${ }^{6}$ H. F. Gaul, Ochrona prawna egzekucji w świetle podstaw konstytucyjnych i dogmatycznych, PPE 2003, nr 1, s. 41.

${ }^{7}$ Szerzej na ten temat patrz: S. Biernat, Zasada efektywności prawa wspólnotowego w orzecznictwie Europejskiego Trybunału Sprawiedliwości (w:) Studia z prawa Unii Europejskiej, red. S. Biernat, Kraków 2000, s. 27 i nast.; D. Miąsik, Zasada efektywności prawa wspólnotowego (w:) Stosowanie prawa Unii Europejskiej przez sądy, red. A. Wróbel, Kraków 2005, s. 315-316.

8 A. Wróbel, Autonomia proceduralna państw..., s. 37. Zasada efektywności, według tego autora, oznacza umożliwienie jednostkom dochodzenia przed sądami państw członkowskich pełnego przestrzegania oraz przestrzegania praw a także ochrony wynikającej z prawa wspólnotowego. Przenosząc powyższe uwagi na grunt tytułowych rozważań, należy wspomnieć o prawie do egzekucji wynikającym z art. 47 zd. 1 Karty Praw Podstawowych UE. 
uzyskać dobrowolnie9. Wobec powyższego, egzekucja sądowa ${ }^{10}$, stanowiąca istotę postępowania egzekucyjnego, powinna przebiegać w sposób sprawny i szybki. Sprawność egzekucji gwarantują stosowane przez organy egzekucyjne, tj. komornika oraz sąd, środki przymusu przewidziane przez ustawę procesową ${ }^{11}$. Przepisy zawarte w art. 758-1088 k.p.c. stanowią wyraz usankcjonowania ochrony prawnej, którą państwo zapewnia wierzycielowi egzekwującemu ${ }^{12}$. Ustawodawca jest zobligowany do tego, by zapewnić warunki sprawiedliwego rozpoznania i rozpatrzenia sprawy, a ponadto umożliwić wykonanie orzeczenia. Sprawna egzekucja sądowa sprzyja pogłębianiu zaufania obywateli do organów wymiaru sprawiedliwości, a także realizuje istotę państwa prawa.

Skuteczność sądowej ochrony wierzyciela determinuje wcielenie w praktykę zasad postępowania egzekucyjnego. Celowi temu sprzyja silna dyspozycyjność postępowania egzekucyjnego. Zgodnie z jej regułami dysponentem postępowania egzekucyjnego jest wierzyciel. Przyspieszeniu postępowania egzekucyjnego służy ponadto zasada formalizmu, przewidująca m.in. dyscyplinę co do czasu, miejsca i formy dokonania określonych czynności.

\section{Zasada sprawnej egzekucji sądowej w orzecznictwie strasburskim}

Wykonanie wyroku lub postanowienia, niezależnie od sądu, który je wydał, należy uznać za integralną część procesu w rozumieniu art. 6 ust. 1 zd. $1 \mathrm{EKPC}^{13}$. W doktrynie podkreśla się, iż jednostka, która uzyskała wyrok sądowy rozstrzygający o odpowiedzialności, ma wypływające $\mathrm{z}$ art. 6 ust. 1 zd. 1 EKPC prawo do żądania jego wykonania, tj. prawo do egzekucji (right to its enforcement) ${ }^{14}$. Prawo strony do wykonania wyroku powinno być rozumiane jako wykonanie

9 E. Wengerek, Sądowe postępowanie egzekucyjne w sprawach cywilnych, Warszawa 1978, s. 9.

${ }^{10}$ Egzekucję, stanowiącą trzon postępowania egzekucyjnego, określa się jako całokształt środków przymusu właściwych dla określonego sposobu egzekucji, jakie organ egzekucyjny może w określonej kolejności zastosować w ramach wybranego przez wierzyciela sposobu egzekucji, w celu zaspokojenia wierzyciela zgodnie z treścią tytułu wykonawczego - zob. R. Kowalkowski (w:) Encyklopedia egzekucji sądowej, Sopot 2002, s. 61. Egzekucja stanowi też proces służący urzeczywistnieniu norm prawa materialnego - zob. S. Gołąb, Z. Wusatowski, Kodeks postępowania cywilnego, część druga, Kraków 1933, s. 1; P. Cioch. J. Nowińska, Postępowanie cywilne, Warszawa 2007, s. 373-374.

${ }_{11}$ Kodeks postępowania cywilnego. Komentarz, t. 2, red. Z. Resich, W. Siedlecki, Warszawa 1976, s. 1076.

12 Z. Szczurek (w:) Egzekucja sądowa w Polsce, red. Z. Szczurek, Sopot 2007, s. 32. Przepisy usprawniające egzekucję objęte są także licznymi przepisami ustaw zwykłych oraz unijnych aktów prawnych - szerzej na ten temat w zakresie skuteczności egzekucji świadczeń alimentacyjnych patrz: M. Rzewuska, Skuteczność egzekwowania świadczeń alimentacyjnych należnych małoletnim od dłużników ukrywających się za granica, Palestra 2011, nr 11-12, s. 76-78.

13 Zob. uzasadnienie wyroku TK z dnia 27 maja 2008 r., P 59/07, OTK-A 2008, nr 4, poz. 64.

14 P. Hofmański, A. Wróbel (w:) Konwencja o Ochronie Praw Człowieka..., op. cit. 
pełne i wyczerpujące, a nie tylko częściowe ${ }^{15}$. Należy wobec tego opowiedzieć się za istnieniem prawa do egzekucji, które wynika również z przepisu art. 6 ust. 1 EKPC. Prawo do rzetelnego procesu sądowego, objęte powyższym przepisem, obejmuje liczne gwarancje procesowe. Warto w tym miejscu zaznaczyć, iż gwarancjami tymi są, po pierwsze, sprawiedliwość proceduralna, do drugie, prawo dostępu do sądu umożliwiające dochodzenie na drodze sądowej praw i obowiązków cywilnoprawnych oraz po trzecie prawo do wykonania wyroku wydanego w sprawie cywilnej ${ }^{16}$. Prawo do wykonania orzeczenia sądowego wiąże się z prawem do jego wykonania w drodze egzekucji, a ponadto wykonania w rozsądnym terminie. Problem przewlekłości postępowania, w tym również egzekucyjnego, stanowi przedmiot licznych judykatów ETPC, co obrazuje jego skalę oraz doniosłość. Przegląd orzecznictwa ETPC w ujęciu statystycznym wykazuje, iż znaczny odsetek wyroków Trybunału strasburskiego wydawanych jest na tle niewykonywania prawomocnych wyroków sądowych, w znacznym stopniu łącząc się z przewlekłością postępowania ${ }^{17}$. Potrzeba przeprowadzenia postępowania egzekucyjnego oraz samej egzekucji sądowej w sposób sprawny została dostrzeżona w orzecznictwie ETPC. Trybunał w Strasburgu niejednokrotnie podkreślał, iż skuteczność egzekucji sądowej stanowi element efektywnego wymiaru sprawiedliwości państw sygnatariuszy Konwencji o Ochronie Praw Człowieka i Podstawowych Wolności ${ }^{18}$. W świetle orzecznictwa ETPC wykonanie wyroku sądowego stanowi integralną część „procesu” w rozumieniu art. 6 ust. 1 EKPC ${ }^{19}$.

Trybunał w Strasburgu zważył, iż opóźnienie w wykonywaniu wyroku może zostać uznane za uzasadnione w szczególnych okolicznościach. Podkreślił on jednak, że zwłoka pojawiająca się na etapie wykonania orzeczenia nie może naruszać istoty prawa chronionego przez art. 6 ust. 1 EKPC. W wyroku z dnia 15 czerwca 2006 r., w sprawie Kazmina przeciwko Rosji, ETPC zwa-

${ }_{15}$ Wyroki ETPC z dnia 31 marca 2005 r. w sprawie Affaire Matheus przeciwko Francji, skarga nr 62740/00 oraz z dnia 2 marca 2004 r. w sprawie Sabin Popescu przeciwko Rumunii, skarga nr 48102/99 - wszystkie wyroki ETPC wymienione w niniejszym opracowaniu dostępne są na stronie internetowej www.echr.coe.int [dostęp: 11.04.2017].

${ }^{16}$ M. Purchase, E. Schutzer-Weismann, Human Rights Practice, Article 6 Right to a Fair Trial, Londyn 2006, s. 6001-6002, podaję za: P. Hofmański, A. Wróbel (w:) Konwencja o Ochronie Praw Człowieka i Podstawowych Wolności. Komentarz do artykułów 1-18. Tom I. Komentarz, red. L. Garlicki, Warszawa 2010, s. 241 i nast.

${ }_{17}$ P. Hofmański, A. Wróbel (w:) Konwencja o Ochronie Praw Człowieka..., op. cit.

${ }_{18}$ Por. wyroki ETPC z dnia 28 lipca 1999 r. w sprawie Immobiliare Saffi przeciwko Włochom, skarga nr 22774/93; z dnia 19 marca 1997 r. w sprawie Hornsby przeciwko Grecji, skarga nr 18357/91; z dnia 20 lipca 2000 r. w sprawie Antonetto przeciwko Włochom, skarga nr 15918/89.

${ }_{19}$ Wyrok ETPC z dnia 28 lipca 1999 r. w sprawie Immobiliare Saffi przeciwko Włochom, skarga nr 22774/98; wyrok ETPC z dnia 12 października 2006 r. w sprawie Orha przeciwko Rumunii, skarga nr 1486/02; wyrok ETPC z dnia 23 września 2008 r. w sprawie Samoilă i inni przeciwko Rumunii, skarga nr 14073/03. Zob. też P. Pogonowski, Postępowanie zabezpieczające i egzekucyjne, Warszawa 2007, s. 103. 
żył, iż prawo skarżącej do wyegzekwowania pomyślnie dla niej zakończonego procesu nie może zostać zablokowane z powodu rzekomych trudności finansowych doświadczanych przez państwo ${ }^{20}$. Naruszeniem Konwencji może być nieracjonalnie długie opóźnienie w wykonaniu prawomocnego wyroku. Wspomniana racjonalność opóźnienia powinna być każdorazowo oceniana z uwzględnieniem stopnia złożoności postępowania wykonawczego, postawy skarżącego (wierzyciela) i kompetentnych organów oraz wysokości i charakteru zasądzonej rekompensaty ${ }^{21}$. ETPC respektuje terminy przewidziane na przeprowadzenie postępowania wykonawczego w przepisach krajowych państw sygnatariuszy Konwencji. Przekroczenie tych terminów ipso facto nie oznacza jednak automatycznie naruszenia postanowień Konwencji. Pewne opóźnienie $\mathrm{w}$ przeprowadzeniu postępowania egzekucyjnego może być bowiem w określonych okolicznościach uznane za uzasadnione, ale w żadnym wypadku nie może ono naruszać istoty praw chronionych ${ }^{22}$. W wyroku z dnia 28 lipca 1999 r., w sprawie Immobiliare Saffi przeciwko Włochom, Trybunał w Strasburgu podkreślił, że zawieszenie wykonania wyroku sądowego może mieć miejsce tylko wyjątkowo i trwać przez okres czasu, który jest konieczny ze względu na istnienie potrzeby satysfakcjonującego rozwiązania problemu dotyczącego porządku publicznego ${ }^{23}$.

ETPC uznał swoją właściwość w zakresie badania, czy organy krajowe spełniły ciążący na nich pozytywny obowiązek wykonania wyroku wydanego przeciwko podmiotowi prywatnemu na rzecz wierzyciela ${ }^{24}$. Władze państwa są bowiem zobowiązane wdrożyć wszelkie niezbędne wysiłki, aby w pełni i we właściwym czasie wyegzekwować wyrok sądu ${ }^{25}$. Państwo traktowane jest przez Trybunał w Strasburgu jako „depozytariusz władzy publicznej” („dépositaire de la force publique"), który powinien działać w sposób rzetelny w celu pomocy wierzycielowi w dążeniu do wykonania korzystnego dla niego rozstrzygnięcia ${ }^{26}$. Prawo do obrony przed sądem, zagwarantowane w artykule 6 ust. 1 Konwencji

20 Por. wyrok ETPC z dnia 15 czerwca 2006 r. w sprawie Kazmina przeciwko Rosji, skarga nr 72374/01. Tak też w wyroku ETPC z dnia 24 czerwca 2008 r. w sprawie Cone przeciwko Rumunii, skarga nr 35935/02.

${ }_{21}$ Decyzja ETPC z dnia 22 lutego 2011 r. w sprawie Gaftoniuc przeciwko Rumunii, skarga nr 30934/05.

22 Wyrok ETPC z dnia 15 stycznia 2009 r. w sprawie Burdov przeciwko Rosji nr 2, skarga nr 33509/04; wyrok ETPC z dnia 7 czerwca 2011 r. w sprawie Güler i Kekeç przeciwko Turcji, skarga nr 33994/06; decyzja ETPC z dnia 24 listopada 2005 r. w sprawie Immobiliare Saffi S.R.L. przeciwko Włochom, skarga nr 22774/93.

23 Wyrok ETPC z dnia 28 lipca 1999 r. w sprawie Immobiliare Saffi przeciwko Włochom, skarga nr 22774/98.

24 Wyrok ETPC z dnia 7 czerwca 2005 r. w sprawie Fuklev przeciwko Ukrainie, skarga nr 71186/01.

${ }^{25}$ Wyrok ETPC z dnia 14 września 2010 r. w sprawie Chiş przeciwko Rumunii, skarga nr 3360/03.

${ }^{26}$ Wyrok ETPC z dnia 9 grudnia 2008 r. w sprawie Ciocan przeciwko Rumunii, skarga nr 6580/03. 
należy interpretować w świetle preambuły do Konwencji, która deklaruje m.in., iż praworządność rozumiana jako rządy prawa jest częścią wspólnego dziedzictwa Umawiających się Państw europejskich. Jednym z podstawowych aspektów praworządności jest zasada pewności prawa, która aktualizuje się w stosunku do wykonania ostatecznych rozstrzygnięć sądowych. Odstępstwa od tej zasady dopuszczalne są jedynie w nielicznych sytuacjach. Państwa sygnatariusze Konwencji mogą, w wyjątkowych okolicznościach i korzystając ze swoich uprawnień dyskrecjonalnych, interweniować w postępowaniu o wykonanie orzeczenia sądowego, lecz konsekwencje takiej interwencji nie powinny prowadzić do sytuacji, gdy wykonanie orzeczenia jest uniemożliwione lub nadmiernie opóźnione ${ }^{27}$.

Trybunał w Strasburgu przypomniał, iż jakkolwiek wykonanie prawomocnego orzeczenia wydanego przez sąd należy traktować jako integralną część procesu dla celów art. 6 ust. 1 Konwencji, to jednak prawo do wykonania prawomocnego orzeczenia sądowego nie może mieć charakteru absolutnego. Prawo „dostępu do sądu” (right of „access to court”) nie nakłada na państwa zobowiązania do wykonania każdego orzeczenia o charakterze cywilnym, bez uwzględnienia konkretnych okoliczności sprawy. Państwo ma jedynie pozytywny obowiązek zorganizowania systemu wykonywania orzeczeń sądowych, który jest skuteczny zarówno w teorii jak i w praktyce oraz zapewnia, iż postępowanie egzekucyjne będzie przeprowadzone bez zbędnej zwłoki. Gdy władze państwowe, zobowiązane do działania w celu wyegzekwowania wyroku sądowego, nie realizują powyższego obowiązku, wówczas brak wymaganej aktywności może powodować pociągnięcie ich do odpowiedzialności na gruncie artykułu 6 ust. 1 Konwencji ${ }^{28}$.

\section{3. Źródła zasady sprawnej egzekucji sądowej}

Jak wynika z dotychczasowych rozważań, postępowanie egzekucyjne podobnie jak postępowanie rozpoznawcze, podlega gwarancjom zawartym $\mathrm{w}$ art. 6 ust. 1 zd. 1 EKPC. Przepis ten stanowi, iż każdy ma prawo do sprawiedliwego i publicznego rozpatrzenia jego sprawy w rozsądnym terminie przez niezawisły i bezstronny sąd ustanowiony ustawą przy rozstrzyganiu o jego prawach i obowiązkach o charakterze cywilnym albo o zasadności każdego oskarżenia w wytoczonej przeciwko niemu sprawie karnej. Do przepisu tego literalnie nawiązuje brzmienie art. 45 ust. 1 Konstytucji RP. Należy uznać, iż wzorzec konstytucyjnego prawa do sądu obejmuje treść art. 6 ust. 1 EKPC. TK wskazał, iż zasada prawa do sądu zawarta w art. 45 ust. 1 Konstytucji RP chroni egzeku-

${ }^{27}$ Wyrok ETPC z dnia 1 kwietnia 2010 r. w sprawie Margushin przeciwko Rosji, skarga nr 11989/03.

${ }^{28}$ Wyrok ETPC z dnia 19 stycznia 2010 r. w sprawie Voda przeciwko Rumunii, skarga nr 35812/02; wyrok ETPC z dnia 19 grudnia 2002 r. w sprawie Paola Esposito przeciwko Włochom, skarga nr 30883/96. 
cję prawomocnych, obowiązujących wyroków, które w państwie akceptującym zasadę rządów prawa nie mogą pozostawać niewykonalne na szkodę jednej ze stron. Ich egzekucja nie może być opóźniona bez właściwego usprawiedliwienia. Prawo do sądu jest iluzoryczne, gdy porządek prawny państwa umożliwia zaniechanie wykonania ostatecznego i obowiązującego orzeczenia.

Przechodząc na grunt prawa krajowego należy zatem podkreślić, iż zasada sprawnej egzekucji sądowej znajduje swoje podstawowe źródło w art. 45 ust. 1 Konstytucji RP, statuującym prawo do sądu. Nie ma bowiem przeszkód, by przepis ten odnosić również do postępowania egzekucyjnego ${ }^{29}$. Prawo do sądu nie może ograniczać się jedynie do prawa do wydania orzeczenia w sprawie, tj. merytorycznego rozpoznania i rozstrzygnięcia sprawy cywilnej, gdyż obejmuje ono ponadto prawo do żądania wykonania tego orzeczenia w drodze egzekucji ${ }^{30}$. Jak wskazuje się w doktrynie oraz orzecznictwie, postępowanie egzekucyjne powinno być uregulowane w sposób sprzyjający szybkości postępowania, co realizuje konstytucyjną zasadę prawa do sądu ${ }^{31}$. Zasada sprawnej egzekucji sądowej, rozumiana jako skrócenie czasu potrzebnego na zaspokojenie wierzycieli, wywodzi się z prawa do rozpoznania sprawy w rozsądnym terminie, które to prawo stanowi komponent ogólniejszego prawa do sądu, zawartego w art. 45 ust. 1 Konstytucji RP. Prawo do rozpatrzenia sprawy przez sąd bez nieuzasadnionej zwłoki należy rozumieć jako definitywne zaspokojenie roszczeń wierzyciela ${ }^{32}$.

Jak podkreślił TK, wykonalność wyroków sądowych realizuje także zasadę demokratycznego państwa prawnego, wyrażoną w przepisie art. 2 Konstytucji $\mathrm{RP}^{33}$. Podobnie w literaturze J. Oniszczuk zauważył, iż z zasady demokratycznego państwa prawnego wynika nakaz podjęcia przez umocowane w prawie organy i instytucje działań bezpośrednio zmierzających do wyegzekwowania postanowień zawartych w prawomocnym orzeczeniu wydanym przez sądy sprawujące w Rzeczypospolitej Polskiej wymiar sprawiedliwości ${ }^{34}$.

Na gruncie prawa procesowego źródłem zasady sprawnej egzekucji sądowej jest przepis art. $6 \$ 1$ in principio k.p.c., który stanowi, iż sąd powinien przeciwdziałać przewlekaniu postępowania. Postulat szybkości postępowania objęty wspomnianym przepisem, na mocy art. $13 \$ 2$ k.p.c. należy stosować odpowiednio

29 Por. wyrok TK z dnia 19 lutego 2008 r., P 49/06, OTK-ZU 2008, nr 1, poz. 5.

30 Wyrok TK z dnia 24 lutego 2003 r., K 28/02, OTK-A 2003, nr 2, poz. 13.

31 F. Zedler, Sadowe postępowanie egzekucyjne $w$ orzecznictwie Trybunału Konstytucyjnego w latach 1985-2008 (w:) Orzecznictwo Trybunału Konstytucyjnego a kodeks postępowania cywilnego, red. T. Ereciński, K. Weitz, Warszawa 2010, s. 223 i 245; M. Jabłoński, S. Jarosz-Żukowska, Prawo do sądu (w:) Prawa i wolności I i II generacji, red. A. Florczak, B. Bolechów, Toruń 2006, s. 137; wyrok TK z dnia 4 listopada 2010 r., K 19/06, OTK-A 2010, nr 9, poz. 96.

${ }^{32}$ Wyrok TK z dnia 4 listopada 2010 r., K 19/06, OTK-A 2010, nr 9, poz. 96.

33 Zob. uzasadnienie wyroku TK z dnia 4 kwietnia 2001 r., K 11/00, OTK 2001, nr 3, poz. 54.

34 J. Oniszczuk, Konstytucja Rzeczypospolitej Polskiej w orzecznictwie Trybunału Konstytucyjnego, Warszawa 2000, s. 119-120. 
do innych niż postępowanie procesowe rodzajów postępowań unormowanych w k.p.c., a zatem również do postępowania egzekucyjnego.

\section{Realizacja zasady sprawnej egzekucji}

Wymaga odnotowania, iż jasne rozgraniczenie funkcji postępowania egzekucyjnego oraz rozpoznawczego przyczynia się do usprawnienia postępowania egzekucyjnego oraz przeciwdziała jego przewlekłości ${ }^{35}$. Sprawna egzekucja sądowa zmierza do zakończenia postępowania egzekucyjnego przez zaspokojenie należności wierzyciela. M. Brulińska podkreśliła, iż egzekucja jest celowa tylko wówczas, gdy podejmowane przez komornika oraz sąd czynności mają wpływ na sprawne zaspokojenie wierzyciela i są zgodne z przepisami prawa egzekucyjnego ${ }^{36}$.

W doktrynie słusznie wskazuje się, iż skuteczne oraz szybkie zaspokojenie wierzyciela w postępowaniu egzekucyjnym jest możliwe przede wszystkim dzięki wiedzy o majątku dłużnika ${ }^{37}$. Z uwagi na powyższe zapewnienie szybkiego dostępu do informacji o majątku dłużnika sprzyja szybkości postępowania egzekucyjnego ${ }^{38}$ oraz determinuje skuteczne powadzenie egzekucji. Chodzi tu zarówno o szybkość, jak i skuteczność egzekucji, łącznie rozumiane jako środki służące efektywnej (sprawnej) egzekucji. Zaspokojenie wierzyciela zgodnie z treścią tytułu wykonawczego wymaga od komornika wiedzy na temat osoby dłużnika oraz jego majątku ${ }^{39}$. Wiedza ta jest uzyskiwana w szczególności poprzez: gromadzenie informacji o stanie majątkowym dłużnika ${ }^{40}$, wyjawienie majątku dłużnika (art. 913-9201 k.p.c.), żądanie wyjaśnień oraz zasięganie informacji, które są niezbędne dla prowadzenia egzekucji (art. $761 \S 1$ k.p.c.),

${ }^{35} \mathrm{~W}$ doktrynie wskazuje się, iż określenie przedmiotu egzekucji oraz podmiotu, przeciwko któremu egzekucja ta ma być prowadzona, dokonuje się na etapie postępowania rozpoznawczego por. F. Zedler, Glosa do uchwały SN z dnia 20 czerwca 2000 r., III CZP 16/00, OSP 2001, z. 9, poz. 133; H. Pietrzkowski (w:) Kodeks postępowania cywilnego. Komentarz. Tom V. Postępowanie egzekucyjne, red. T. Ereciński, Warszawa 2016, s. 25 i nast. Szerzej na temat przyczyn przewlekłości postępowania egzekucyjnego patrz: D. Olczak-Dąbrowska, Wybrane zagadnienia egzekucji sądowej, Instytut Wymiaru Sprawiedliwości, Warszawa 2016.

${ }^{36}$ M. Brulińska (w:) Wybrane zagadnienia egzekucji sq̨dowej, red. J. Gołaczyński, Warszawa 2008, s. 61.

${ }^{37}$ Z. Szczurek, Wiedza o majątku dtużnika środkiem efektywnego - szybkiego i skutecznego zaspokojenia praw wierzyciela w postępowaniu egzekucyjnym, Gdańskie Studia Prawnicze 2009, t. 21, s. $405-420$.

${ }^{38}$ S. Dalka, J. Świeczkowski, Pozyskiwanie informacji dotyczących majątku dłużnika - prawo czy obowiazek?, PPE 2003, nr 11-12, s. 5-11.

${ }^{39}$ Z. Szczurek, Wiedza o majątku dłużnika..., s. 408.

${ }^{40}$ Co do sposobów gromadzenia informacji o stanie majątkowym dłużnika patrz: Z. Szczurek, Wiedza o majątku dtużnika..., s. 408-410. 
pisemne żądanie komornika udzielenia w trybie art. 2 ust. 5 u.k.s.e. ${ }^{41}$ informacji niezbędnych dla prawidłowego prowadzenia postępowania egzekucyjnego czy też umożliwiających identyfikację składników majątku dłużnika, a także obowiązek informowania wierzyciela przez organ egzekucyjny o postępowaniu egzekucyjnym (art. $760^{1}$ k.p.c.), umożliwiający wierzycielowi dostęp do informacji o innych postępowaniach egzekucyjnych toczących się przeciwko dłużnikowi.

Zapewnienie sprawności postępowania egzekucyjnego, oceniane przez pryzmat celu tego postępowania tj. skutecznej egzekucji, gwarantują ponadto, m.in. ustawowo określone zasady podziału sumy uzyskanej z egzekucji (art. $1023-1040^{1}$ k.p.c.). Mają one tym większe znaczenie praktyczne, gdy suma uzyskana z egzekucji nie wystarcza na zaspokojenie wszystkich wierzycieli lub też wszystkich należności tychże wierzycieli. Przepisy przewidują podział sumy uzyskanej z egzekucji na zasadzie uprzywilejowania albo równorzędności, która występuje w postaci zasady proporcjonalności albo zasady pierwszeństwa ${ }^{42}$.

\section{Zasada sprawnej egzekucji sądowej w orzecznictwie TK}

Celem dopełnienia problematyki dotyczącej zasady sprawnej egzekucji sądowej warto przybliżyć wybrane orzeczenia TK, istotne z uwagi na, po pierwsze, trybunalską analizę określonych instytucji postępowania egzekucyjnego w kontekście zasady sprawnej egzekucji, po drugie zaś, dla zobrazowania zmian legislacyjnych, które dokonały się pod ich wpływem ${ }^{43}$.

Wyrok TK z dnia 27 maja 2008 r., P 59/0744, dotyczył oceny konstytucyjności przepisu art. $969 \$ 3$ k.p.c., regulującego przeznaczenie kwoty z rękojmi utraconej przez nabywcę licytacyjnego lub od niego ściągniętej. Przepis ten, w aktualnym brzmieniu ustalonym na mocy ustawy z dnia 16 września $2011 \mathrm{r}^{45}$, przewiduje, iż z rękojmi utraconej przez nabywcę lub od niego ściągniętej pokrywa się koszty egzekucji związane ze sprzedażą, a reszta wchodzi w skład sumy uzyskanej w egzekucji albo jeżeli egzekucja została umorzona, jest przelewana na dochód Skarbu Państwa. W poprzednim stanie prawnym rękojmia przeznaczana była na pokrycie kosztów egzekucji związanych ze sprzedażą, zaś reszta przelewana

${ }^{41}$ Ustawa z dnia 29 sierpnia 1997 r. o komornikach sądowych i egzekucji, t.j. Dz.U. z 2016 r., poz. 1138 ze zm., dalej jako u.k.s.e.

${ }^{42}$ W. Broniewicz, Postępowanie cywilne w zarysie, Warszawa 1999, s. 456. Szerzej patrz: I. Kunicki, Podział sumy uzyskanej z egzekucji, Sopot 2000, s. 101; Tenże, Zasady podziału sumy uzyskanej z egzekucji, PS 1998, nr 9, s. 88 i nast.

${ }_{43}$ Por. też wyrok TK z dnia 24 lutego 2003 r., K 28/02, OTK-A 2003, nr 2, poz. 13 oraz z dnia 4 kwietnia 2001 r., K 11/00, OTK 2001 nr 3, poz. 54.

${ }^{44}$ OTK-A 2008, $\mathrm{nr}$ 4, poz. 64.

${ }^{45}$ Ustawa z dnia 16 września 2011 r. o zmianie ustawy - Kodeks postępowania cywilnego oraz niektórych innych ustaw, Dz.U. Nr 233, poz. 1381, weszła w życie w dniu 3 maja 2012 r. 
była na dochód Skarbu Państwa. Problem oceny TK, dotyczący konstytucyjności art. $969 \$ 3$ k.p.c. w brzmieniu sprzed wspomnianej nowelizacji, sprowadzał się, m.in. do oceny stanowiska sądu rejonowego zadającego pytanie prawne, zgodnie z którym przejęcie przez państwo kwoty uzyskanej z egzekucji przy braku zaspokojenia wierzycieli jest rażąco sprzeczne z ideą sprawiedliwości i nie zapewnia należytej ochrony praw majątkowych egzekwującym wierzycielom. Sąd rejonowy stwierdził bowiem, iż możliwość zaspokojenia wierzyciela z utraconej przez licytanta rękojmi przyspieszałaby zakończenie postępowania egzekucyjnego przynajmniej w części, w której egzekwowana należność zostanie pokryta $\mathrm{z}$ uzyskanej rękojmi. Pozbawienie wierzyciela prawa zaspokojenia z rękojmi powoduje natomiast naruszenie prawa do rozpoznania sprawy w rozsądnym terminie, gdyż uniemożliwia zaspokojenie przynajmniej części przysługujących wierzycielowi należności materialnoprawnych ${ }^{46}$.

TK, odmawiając uznania art. $969 \$ 3$ k.p.c. za sprzeczny z Konstytucją RP, stwierdził, iż przeznaczenie utraconej rękojmi dla wierzycieli, nie zaś dla Skarbu Państwa, „byłoby bardziej przyjazne dla ostatecznego efektu egzekucji”. TK zaznaczył, iż wielkość udziału utraconej rękojmi w ogólnej sumie zadłużenia obciążającej licytowany majątek jest niewielka. Związek między losami ulegającej przepadkowi rękojmi a przeprowadzeniem skutecznej licytacji został natomiast określony jako „luźny”.

Mimo odmowy uznania art. $969 \$ 3$ k.p.c. za sprzeczny z Konstytucją RP, ustawodawca dostrzegł problem przeznaczenia utraconej rękojmi, decydując się na rozwiązanie nawiązujące do przedwojennego k.p.c. $z 1930$ r. ${ }^{47}$ De lege lata jest to bez wątpienia regulacja korzystna dla wierzycieli, która sprzyja efektywnie przeprowadzonej egzekucji. Z uzasadnienia projektu ustawy nowelizującej przepis art. $969 \$ 3$ k.p.c. wynika jednoznacznie ścisły związek rękojmi z celem egzekucji, którym jest zaspokojenie wierzyciela ${ }^{48}$.

Zatrzymując się przy ocenie zmian w postępowaniu egzekucyjnym, które dokonały się na mocy ustawy nowelizującej z dnia 16 września 2011 r., można stwierdzić, iż zmierzały one generalnie w kierunku wzmocnienia efektywności obowiązującego systemu egzekucji. Celowi temu sprzyja, po pierwsze, podwyższenie górnej granicy dopuszczalnych grzywien pieniężnych, które uregulowane są w przepisach art. 1052 k.p.c. ${ }^{49}$ oraz 1053 k.p.c. ${ }^{50}$ Drugim rozwiązaniem nasta-

\footnotetext{
${ }^{46}$ Op. cit.

47 Rozporządzenie Prezydenta RP z dnia 29 listopada 1930 r. - Kodeks postępowania cywilnego, Dz.U. z 1930 r. Nr 83, poz. 651. Akt uchylony z dniem 1 stycznia 1965 r.

${ }^{48}$ Zob. druk sejmowy nr 4332, Sejm VI Kadencji, www.sejm.gov.pl [dostęp:11.04.2017].

${ }^{49}$ Wysokość grzywny wymierzona przez sąd w jednym postępowaniu to maksymalnie 10 tysięcy złotych, zaś ogólna suma grzywien w tej samej sprawie nie może przewyższać 1 miliona złotych.

${ }^{50} \mathrm{~W}$ przypadku zamiany grzywny na areszt liczy się jeden dzień aresztu od pięćdziesięciu do tysiąca pięciuset złotych grzywny.
} 
wionym na wzrost skuteczności egzekucji jest przyznanie nowych kompetencji zarówno sądowi, jako organowi egzekucyjnemu, jak i wierzycielowi. Mowa tu o przepisie art. $1050^{1}$ k.p.c., który przewiduje konstrukcję zastąpienia rygoru grzywny, pod którym to rygorem dłużnik ma obowiązek wykonać czynność niezastępowalną, innym zagrożeniem, a mianowicie nakazaniem zapłaty na rzecz wierzyciela i na jego wniosek określonej sumy pieniężnej za każdy dzień zwłoki w wykonaniu czynności. Nakazanie dłużnikowi zapłaty za zwłokę jest niezależne od roszczeń przysługujących dłużnikowi na zasadach ogólnych. Prawomocne postanowienie sądu nakazujące dłużnikowi zapłatę stanowi tytuł wykonawczy bez potrzeby nadawania mu klauzuli wykonalności (art. 1050 $\$ 2$ zd. 3 k.p.c.), co tylko przyspiesza postępowanie. Po trzecie, należy przytoczyć przepis art. $1051^{1}$ k.p.c., który przewiduje konstrukcję wzorowaną na wspomnianym powyżej przepisie art. $1050^{1}$ k.p.c. Chodzi tu o nakazanie dłużnikowi, by za dokonane naruszenie dokonał zapłaty sumy pieniężnej na rzecz wierzyciela i na jego wniosek, zamiast grzywny, jeżeli dłużnik nie przestrzegał obowiązku zaniechania lub nieprzeszkadzania czynnościom wierzyciela. Prawomocne postanowienie sądu nakazujące dłużnikowi zapłatę jest tytułem wykonawczym bez nadawania mu klauzuli wykonalności (art. $1051^{1} \$ 3$ k.p.c.).

Powracając do głównego nurtu rozważań nad orzecznictwem trybunalskim, należy dalej wspomnieć o wyroku z dnia 4 listopada 2010 r., K 19/06 ${ }^{51}$, w którym TK stwierdził niezgodność art. $1046 \$ 4$ k.p.c. z art. 45 ust. 1 Konstytucji RP. Na drodze do efektywnej egzekucji niejednokrotnie pojawiają się trudności wierzycieli w egzekwowaniu wyroków orzekających eksmisję innej osoby z ich mieszkania, w których sąd nie przyznał dłużnikowi prawa do lokalu socjalnego lub zamiennego. W stanie prawnym sprzed ustawy nowelizującej k.p.c. z dnia 16 września 2011 r., komornik wykonując obowiązek opróżnienia lokalu służącego zaspokojeniu potrzeb mieszkaniowych dłużnika na podstawie tytułu wykonawczego, z którego nie wynika prawo dłużnika do lokalu socjalnego lub zamiennego, miał obowiązek wstrzymać się z dokonaniem czynności do czasu, gdy gmina wskaże tymczasowe pomieszczenie lub gdy dłużnik znajdzie takie pomieszcze$n^{2} e^{52}$. Taki stan prawny służył ochronie pozycji dłużnika. TK we wspomnianym wyroku uznał, iż brak precyzyjnego określenia obowiązków podmiotów wskazanych w art. $1046 \$ 4$ i 5 k.p.c. związanych z zapewnieniem dłużnikowi pomiesz-

${ }^{51}$ OTK-A 2010, nr 9, poz. 96.

${ }_{52}$ Problem tzw. „eksmisji na bruk” jest dostrzegany także w orzecznictwie strasburskim, gdzie akcentuje się konieczność zaspokojenia minimalnych potrzeb mieszkaniowych osób eksmitowanych. Dopuszczalność eksmisji bez zapewnienia lokalu lub pomieszczenia godzi w postanowienia art. 8 Konwencji, gwarantującego prawo do ochrony życia prywatnego i rodzinnego oraz poszanowania mieszkania - por. wyroki ETPC z dnia 24 maja 2007 r. w sprawie Tuleshov przeciwko Rosji, skarga nr 32718/02; z dnia 9 października 2007 r. w sprawie Stanková przeciwko Słowacji, skarga nr 7205/02 oraz z dnia 15 stycznia 2009 r. w sprawie Ćosić przeciwko Chorwacji, skarga nr 28261/06. 
czenia tymczasowego powoduje, że podmioty te nie podejmują efektywnych czynności w kierunku zaspokojenia wierzyciela. Wobec powyższego komornik, wstrzymując czynności egzekucyjne na niedający się przewidzieć czas, nie jest w stanie wykonać prawomocnego wyroku sądowego. Sytuacja ta przedkładała się w praktyce na niemożność wykonania wyroków eksmisyjnych lub też ich wykonanie ze znacznym opóźnieniem, ze szkodą dla wierzycieli ${ }^{53}$. Stan przewlekłości postępowania egzekucyjnego powstający w takiej sytuacji powodował, że sądowa ochrona udzielana wierzycielowi w praktyce okazywała się iluzoryczna ${ }^{54}$.

W aktualnym stanie prawnym komornik wstrzyma się z wykonaniem obowiązku opróżnienia lokalu nie dłużej niż przez 6 miesięcy, zaś po upływie tego czasu komornik usunie dłużnika do noclegowni, schroniska lub innej placówki zapewniającej miejsca noclegowe wskazanej przez gminę (art. $1046 \$$ 4 zd. 2 i 3 k.p.c.). Obecne rozwiązanie sprzyja usprawnieniu eksmisji z lokalu mieszkalnego, powodując, iż wierzyciel ma do dyspozycji dwa dodatkowe środki zmierzające do ochrony jego praw. Należy bowiem mieć na względzie, iż $\mathrm{w}$ razie niedopełnienia przez komornika ciążących na nim obowiązków wierzycielowi przysługuje skarga na czynności komornika (art. 767 i nast. k.p.c.). Ponadto, jeżeli gmina nie wykona obowiązku wskazania komornikowi noclegowni, schroniska lub innej placówki noclegowej, wówczas zrealizuje się prawo wierzyciela do wystąpienia z powództwem odszkodowawczym ${ }^{55}$.

\section{Zasada dyspozycyjności i zasada formalizmu oraz ich przejawy}

Jak słusznie wskazuje się w literaturze postępowanie egzekucyjne odróżnia się od postępowania rozpoznawczego także pod względem naczelnych zasad postępowania cywilnego. Pewne zasady rządzące postępowaniem rozpoznawczym nie znajdują odzwierciedlenia w postępowaniu egzekucyjnym $\mathrm{w}$ takim kształcie, jak w postępowaniu rozpoznawczym (np. zasada prawdy materialnej czy zasada bezpośredniości) ${ }^{56}$. Należy zgodzić się ze stwierdzeniem, iż zasady postępowania egzekucyjnego są często odmienne niż zasady postępowania rozpoznawczego ${ }^{57}$. Postępowanie egzekucyjne wyróżnia bowiem działanie

53 Istnieją wprawdzie roszczenia odszkodowawcze, które przysługują wierzycielowi od dłużnika w myśl art. 18 ustawy z dnia 21 czerwca 2001 r. o ochronie praw lokatorów, mieszkaniowym zasobie gminy i o zmianie Kodeksu cywilnego (Dz.U. z 2016 r., poz. 1610), lecz są one równie trudne do wyegzekwowania.

54 Wyrok TK z dnia 4 listopada 2010 r., K 19/06, OTK-A 2010, nr 9, poz. 96.

55 Por. K. Siwiec, Eksmisja na nowych zasadach, Nieruchomości 2014, nr 6, s. 18.

56 A. Marciniak, Postępowanie egzekucyjne w sprawach cywilnych, Warszawa 2008, s. 30.

${ }^{57}$ K. Kamińska-Krawczyk, Koszty postępowania egzekucyjnego prowadzonego przez komornika sq̨dowego, Warszawa 2016, s. 198 i nast. 
naczelnych zasad postępowania cywilnego, takich jak zasada formalizmu oraz zasada dyspozycyjności ${ }^{58}$.

Zasada dyspozycyjności, zwana inaczej zasadą rozporządzalności, wskazuje, iż możliwość rozporządzania przedmiotem postępowania (dyspozycyjność materialna) oraz środkami zaczepnymi i obronnymi w postępowaniu (dyspozycyjność formalna) służy podmiotom, których praw i obowiązków dotyczy dane postępowanie $^{59}$. Dysponentem postępowania egzekucyjnego jest wierzyciel ${ }^{60}$, z pewnymi ograniczeniami umożliwiającymi wszczęcie egzekucji z urzędu ${ }^{61}$, czy też dokonanie pewnych czynności przez sąd z urzędu ${ }^{62}$.

Silna dyspozycyjność postępowania egzekucyjnego widoczna jest w sytuacjach takich jak, np. nadanie tytułu egzekucyjnemu klauzuli wykonalności (art. 782 $\$ 1$ k.p.c.), wszczęcie i umorzenie egzekucji na wniosek wierzyciela (art. 796 $\$ 1$ k.p.c.), wskazanie we wniosku o wszczęcie egzekucji świadczenia, które ma być spełnione (art. 798 k.p.c.), związanie organu egzekucyjnego wnioskiem o umorzenie postępowania egzekucyjnego (art. 825 pkt 1 k.p.c.) ${ }^{63}$.

Należy dodać, iż dalszymi ważniejszymi przejawami zasady dyspozycyjności w postępowaniu egzekucyjnym są w szczególności: ukaranie przez organ egzekucyjny grzywną w trybie art. $762 \$ 1$ oraz art. $1050 \$ 3$ k.p.c., wezwanie na wniosek wierzyciela nabywcy przedsiębiorstwa lub gospodarstwa rolnego do okazania dokumentów stwierdzających nabycie (art. $789^{1}$ zd. 2 k.p.c.), wniosek wierzyciela o skierowanie egzekucji do nieruchomości dłużnika oraz składników jego majątku, do których przepisy o egzekucji z nieruchomości stosuje się odpowiednio (art. $799 \$ 1$ k.p.c.), ustanowienie kuratora w trybie art. 802, art. $818 \$ 1$, art. $819 \$ 2$, art. $908 \$ 1$ oraz art. $1022^{3}$ k.p.c., zawieszenie postępowania egzekucyjnego (art. 820 k.p.c.) oraz jego podjęcie (art. $820^{3} \$ 2$ k.p.c.), wydanie zaświadczenia o umorzeniu postępowania egzekucyjnego (art. $827 \$ 2$ k.p.c.), przekazanie określonych ruchomości do sprzedaży komisowej przed sprzedażą w drodze licytacji publicznej (art. $867 \$ 4$ k.p.c.), dokonanie sprzedaży w drodze licytacji elektronicznej przez komornika na wniosek wierzyciela (art. 879² oraz art. $879^{10} \$ 2$ k.p.c.), wniosek o odebranie dłużnikowi dokumentów stanowiących dowód wierzytelności (art. $897 \$ 2$ k.p.c.), dokonanie przez komornika czynności zachowawczych na wniosek wierzyciela (art. $901 \$ 3$ k.p.c.), sprzedaż wierzytelności w drodze licytacji lub $\mathrm{z}$ wolnej ręki na wniosek wierzyciela

\footnotetext{
58 S. Cieślak, Formalizm postępowania egzekucyjnego, PPE 2009, nr 12, s. 7 i nast.

59 A. Marciniak (w:) Postępowanie cywilne w zarysie, red. W. Broniewicz, A. Marciniak, I. Kunicki, Warszawa 2016, s. 71.

60 A. Marciniak, Postępowanie egzekucyjne.., s. 31.

${ }_{61}$ Por. art. $796 \$ 2$, art. $883 \$ 2$, art. 1067 , art. 1085 k.p.c.

62 Por. art. 802 , art. $818 \S 1$, art. $819 \S 1$, art. $824 \S 1$, art. $901 \S 3$, art. $910^{2} \S 2$, art. $929 \S 3$, art. 946 $\$ 1$, art. $1064^{15} \$ 2$, art. 1082 , art. $1086 \$ 1$ i $\$ 4$ k.p.c.

${ }^{63}$ A. Marciniak (w:) Postępowanie cywilne..., s. 72.
} 
(art. 904 $\$ 1$ k.p.c.), ustanowienie innego niż dłużnik zarządcy nieruchomości (art. $906 \$ 1$ k.p.c.), odebranie pomieszczeń w zajętej nieruchomości w trybie art. $931 \S 4$ k.p.c., dokonanie opisu i oszacowania na wniosek wierzyciela (art. 942 $\$ 1$ oraz art. $1013^{2} \$ 1$ k.p.c.), wystawienie na licytację wydzielonej części zajętej nieruchomości na wniosek wierzyciela (art. $946 \$ 1$ k.p.c.), wyznaczenie przez komornika drugiej licytacji (art. 983 k.p.c.) oraz ponownej, gdy sąd odmówi przybicia (art. 992 k.p.c.), sąd na wniosek wierzyciela nakaże dłużnikowi wyjawienie dokumentów lub rzeczy w trybie art. 1045 k.p.c., wniosek wierzyciela o wezwanie przez sąd dłużnika do dokonania czynności, którą może wykonać także inna osoba (art. $1049 \$ 1$ k.p.c.) czy też wniosek o wyznaczenie przez sąd terminu do dokonania czynności niezastępowalnej (art. $1050 \$ 1$ k.p.c.).

Zasada sprawnej egzekucji wiąże się ściśle z zasadą formalizmu postępowania, która $\mathrm{z}$ kolei określa formę, miejsce i czas dokonywania poszczególnych czynności w postępowaniu egzekucyjnym. Zasada formalizmu postępowania cywilnego stanowi o tym, iż postępowanie to jest prawnie zorganizowanym pod względem formy, miejsca i czasu działaniem ludzkim składającym się z czynności postępowania wykonywanych przez swoje podmioty. Forma czynności postępowania nie tylko chroni uczestników postępowania przed samowolą organów oraz innych uczestników postępowania, wprowadzając przewidywalność skutków prawnych określonych działań, lecz ma decydujące znaczenie dla usprawnienia tego postępowania. S. Cieślak podkreślił, iż podwyższony stopnień sformalizowania, zdeterminowany przez bardzo szczegółową regulację formy, miejsca i czasu podejmowania czynności egzekucyjnych, jest widoczny szczególnie w odniesieniu do czynności komornika sądowego ${ }^{64}$. Z powyższych trzech konglomeratów zasady formalizmu postępowania, to właśnie aspekt czasu wyznaczonego dla dokonania poszczególnych czynności ma najistotniejsze znaczenie w kontekście realizacji zasady sprawnej egzekucji sądowej. Ustawowe określenie czasu dokonywania czynności postępowania egzekucyjnego służy bowiem jego przyspieszeniu. Opóźnienie wykonania prawomocnego orzeczenia sądowego może budzić zastrzeżenia w kontekście realizacji celu postępowania egzekucyjnego, jakim jest zaspokojenie wierzyciela. Należy podkreślić, iż brak efektywnych działań podejmowanych w postępowaniu egzekucyjnym przez organy egzekucyjne także może przyczynić się do przewleczenia tego postępowania.

Powołując się na znaczenie zasady formalizmu dla realizacji zasady sprawności egzekucji sądowej należy przywołać trzy grupy terminów. Są to mianowicie po pierwsze, terminy do dokonania czynności organu procesowego (np. termin do nadania tytułowi egzekucyjnemu klauzuli wykonalności - art. $781^{1}$ k.p.c.), po drugie, terminy do dokonywania czynności organu egzekucyjnego (np. termin

${ }^{64}$ S. Cieślak, Formalizm postępowania..., s. 9 i nast. 
do dokonania opisu i oszacowania nieruchomości - art. 942 k.p.c., termin licytacji - art. 952 k.p.c., termin obwieszczenia o licytacji - art. 955 k.p.c., termin do rozpoznania skargi na czynności komornika sądowego - art. $767^{2}$ k.p.c.) oraz po trzecie, terminy do dokonania czynności uczestników postępowania egzekucyjnego ${ }^{65}$. Trzecia grupa terminów obejmuje terminy wskazane w drodze ustawy (np. termin dla dłużnika do powiadomienia o każdej zmianie miejsca pobytu trwającej dłużej niż miesiąc - art. $761 \$ 3$ k.p.c., termin do wniesienia skargi na czynności komornika - art. $767 \$ 4$ k.p.c., termin do wytoczenia powództwa o pozbawienie tytułu wykonawczego wykonalności w stosunku do dłużnika - art. $791 \S 3$ k.p.c., termin do żądania przez dłużnika sporządzenia uzasadnienia postanowienia o nadaniu klauzuli wykonalności i doręczenia postanowienia wraz z uzasadnieniem - art. $794^{2} \$ 3$ k.p.c., termin do złożenia wniosku o uchylenie zaświadczenia europejskiego tytułu egzekucyjnego - art. $795^{4} \$ 2$ k.p.c.) albo wyznaczone przez organ egzekucyjny (np. termin do złożenia wykazu majątku i przyrzeczenia - art. $915 \$ 2$ k.p.c., termin dla dłużnika do dokonania czynności - art. $1054 \$ 1$ k.p.c., termin do spełnienia świadczenia przez kierownika właściwej państwowej jednostki organizacyjnej - art. 1060 $\$ 3$ k.p.c., termin dokonania sprzedaży z wolnej ręki - art. $1064^{18} \$ 2$ k.p.c.). Organy egzekucyjne wyznaczają też datę danej czynności egzekucyjnej (np. art. 809 pkt 1, art. $867 \$ 1^{2}$, art. $879^{4} \S 3$, art. $879^{6} \$ 2$, art. $867 \S 3$, art. $945 \$ 1$, art. $953 \S 1$ pkt 2 k.p.c. $)^{66}$.

\section{Podsumowanie}

Każde sądowe postępowanie cywilne narażone zagrożone jest przewlekłością, która zasadniczo negatywnie wpływa na efektywność oraz skuteczność ochrony prawnej udzielanej w tym postępowaniu ${ }^{67}$. Stwierdzenie to zachowuje aktualność także w odniesieniu do postępowania egzekucyjnego. Należy w pełni zgodzić się, iż znaczenie efektywnej egzekucji bywa niekiedy marginalizowane, a tymczasem gwarancja szybkiego wykonania orzeczenia jest kwintesencją sprawiedliwości, zaś samo prawo do wykonania orzeczenia immanentną, stanowi konieczną część składową rzetelnego procesu cywilnego ${ }^{68}$. Zasada sprawnej egzekucji sądowej wykazuje fundamentalne znaczenie dla realizacji praw przysługujących wierzycielowi w postępowaniu egzekucyjnym, jak również dla urzeczywistnienia samego celu postępowania egzekucyjnego. Na gruncie postępowania egzekucyjnego to

${ }^{65}$ Por. też: K. Kamińska-Krawczyk, Koszty postępowania egzekucyjnego..., op. cit.

66 Op. cit.

${ }^{67}$ A. Marciniak (w:) Kodeks postępowania cywilnego. Tom I. Komentarz. Art. 1-366, red. A. Marciniak, K. Piasecki, Warszawa 2016, s. 84.

68 A. Łazarska, Rzetelny proces cywilny, Warszawa 2012, s. 308-309. 
właśnie zasada sprawnej egzekucji sądowej pozwala wyjaśnić „istotę” i znaczenie samej egzekucji. Jak wskazuje się w literaturze, pierwszoplanowym zadaniem zasad postępowania cywilnego jest wyznaczenie ram działania ustawodawcy, co należy rozumieć jako niedopuszczalność wprowadzania przez racjonalnego ustawodawcę regulacji sprzecznych z podstawowymi ideami modelu egzekucji ${ }^{69}$. Zasadne jest zatem przyjęcie, iż zasada sprawnej egzekucji sądowej, podobnie jak inne zasady postępowania cywilnego, wpływa także na praktykę stosowania prawa (poprzez określenie podstawowych form i metod działania organów procesowych oraz uczestników postępowania w ramach szeroko rozumianego wymiaru sprawiedliwości) ${ }^{70}$. Ma ona bez wątpienia niebagatelne znaczenie dla przyjętego kierunku wykładni przepisów o postępowaniu egzekucyjnym. Wprawdzie, zasada sprawnej egzekucji sądowej nie została wymieniona i wskazana wśród naczelnych zasad postępowania cywilnego ${ }^{71}$, lecz nie należy z tej racji umniejszać jej znaczenia. Wręcz przeciwnie, o doniosłości zasady sprawnej egzekucji, rozumianej jako egzekucja szybka oraz skuteczna, świadczą argumenty przedstawione w powyższym wywodzie.

Zasada sprawnej egzekucji wymieniana jest w orzecznictwie Trybunału Konstytucyjnego, a także Trybunału w Strasburgu. Jej ranga dostrzegana jest również przez ustawodawcę, co powoduje, iż szereg nowelizacji procedury cywilnej przeprowadzonych w ostatnich latach w sposób bezpośredni zmierza do wprowadzania takich zmian legislacyjnych, które w najwyższym stopniu dadzą wyraz zasadzie sprawnej egzekucji sądowej. Podobnie, wartość tytułowej zasady dla postępowania egzekucyjnego podkreślają jej silne związki z zasadami konstytucyjnymi, takimi jak zasada prawa do sądu czy zasada demokratycznego państwa prawnego. W świetle powyższego, w pełni zasadne jest stwierdzenie, iż zasada sprawnej egzekucji sądowej determinuje efektywność wymiaru sprawiedliwości, a prawo do egzekucji jest jednym $z$ praw jednostki przyznanych $w$ demokratycznym państwie prawnym urzeczywistniającym zasady sprawiedliwości społecznej.

Z drugiej jednak strony nie sposób nie dostrzec licznych problemów, które pojawiają się w kontekście zapewnienia przebiegu postępowania egzekucyjnego z poszanowaniem tytułowej zasady. Problemy te ogniskują się wokół tezy, iż zasada sprawnej egzekucji w pełni realizuje interes wierzyciela, nie zaś dłużnika. Zróżnicowany status prawny wierzyciela i dłużnika oraz powoda i pozwanego powoduje,

69 T. Demendecki, Rozstrzyganie o kosztach w procesowym postępowaniu cywilnym rozpoznawczym w świetle polskiej regulacji kodeksowej. Studium teoretycznoprawne, Lublin 2011, s. 95.

${ }^{70}$ Op. cit.

${ }^{71}$ Zasady postępowania egzekucyjnego to: zasada prawdy materialnej, zasada formalizmu, zasada dyspozycyjności, zasada kontradyktoryjności, zasada równości (równouprawnienia stron), zasada bezpośredniości, zasada koncentracji materiału procesowego, zasada ustności, zasada jawności, zasada inicjatywy procesowej organów procesowych i egzekucyjnych - por. A. Marciniak, Postępowanie egzekucyjne.., s. 35-46. 
iż zakres ochrony prawnej udzielonej stronom postępowania egzekucyjnego oraz rozpoznawczego jest nierównomierny. Tym większe znaczenie należy przyznać zasadzie proporcjonalności, która wymaga, by respektowanie zasady sprawnej egzekucji sądowej nie prowadziło do naruszenia praw przyznanych dłużnikowi.

\section{Wykaz literatury:}

Biernat S., Zasada efektywności prawa wspólnotowego w orzecznictwie Europejskiego Trybunału Sprawiedliwości (w:) Studia z prawa Unii Europejskiej, red. S. Biernat, Kraków 2000.

Broniewicz W., Postępowanie cywilne w zarysie, Warszawa 1999.

Brulińska M. (w:) Wybrane zagadnienia egzekucji sq̨dowej, red. J. Gołaczyński, Warszawa 2008.

Cieślak S., Formalizm postępowania egzekucyjnego, PPE 2009, nr 12.

Cioch P., Nowińska J., Postępowanie cywilne, Warszawa 2007.

Dalka S., Świeczkowski J., Pozyskiwanie informacji dotyczących majątku dłużnika - prawo czy obowiqzek?, PPE 2003, nr 11-12.

Demendecki T., Rozstrzyganie o kosztach w procesowym postępowaniu cywilnym rozpoznawczym w świetle polskiej regulacji kodeksowej. Studium teoretycznoprawne, Lublin 2011.

Gaul H. F., Ochrona prawna egzekucji w świetle podstaw konstytucyjnych i dogmatycznych, PPE 2003, nr 1.

Gołąb S., Wusatowski Z., Kodeks postępowania cywilnego, część druga, Kraków 1933.

Hofmański P., Wróbel A. (w:) Konwencja o Ochronie Praw Człowieka i Podstawowych Wolności. Komentarz do artykułów 1-18. Tom I. Komentarz, red. L. Garlicki, Warszawa 2010.

Jabłoński M., Jarosz-Żukowska S., Prawo do sq̨du (w:) Prawa i wolności I i Il generacji, red. A. Florczak, B. Bolechów, Toruń 2006.

Kamińska-Krawczyk K., Koszty postępowania egzekucyjnego prowadzonego przez komornika sq̨dowego, Warszawa 2016.

Kmieciak Z., Efektywność sq̨dowej kontroli administracji publicznej, PiP 2010, nr 11.

Kowalkowski R. (w:) Encyklopedia egzekucji sądowej, Sopot 2002.

Kunicki I., Zasady podziału sumy uzyskanej z egzekucji, PS 1998, nr 9.

Kunicki I., Podział sumy uzyskanej z egzekucji, Sopot 2000.

Łazarska A., Rzetelny proces cywilny, Warszawa 2012.

Marciniak A., Postępowanie egzekucyjne w sprawach cywilnych, Warszawa 2008.

Marciniak A. (w:) Postępowanie cywilne w zarysie, red. W. Broniewicz, A. Marciniak, I. Kunicki, Warszawa 2016.

Marciniak A. (w:) Kodeks postępowania cywilnego. Tom I. Komentarz. Art. 1-366, red. A. Marciniak, K. Piasecki, Warszawa 2016.

Miąsik D., Zasada efektywności prawa wspólnotowego, w:, Stosowanie prawa Unii Europejskiej przez sądy, red. A. Wróbel, Kraków 2005.

Olczak-Dąbrowska D., Wybrane zagadnienia egzekucji sądowej, Instytut Wymiaru Sprawiedliwości, Warszawa 2016.

Oniszczuk J., Konstytucja Rzeczypospolitej Polskiej w orzecznictwie Trybunału Konstytucyjnego, Warszawa 2000.

Pietrzkowski H. (w:) Kodeks postępowania cywilnego. Komentarz. Tom V. Postępowanie egzekucyjne, red. T. Ereciński, Warszawa 2016.

Pogonowski P., Postępowanie zabezpieczające i egzekucyjne, Warszawa 2007.

Półtorak N. (w:) System Prawa Administracyjnego. Tom 3. Europeizacja prawa administracyjnego, red. R. Hauser, A. Wróbel, Z. Niewiadomski, Warszawa 2014.

Purchase M., Schutzer-Weismann E., Human Rights Practice, Article 6 Right to a Fair Trial, Londyn 2006. 
Resich Z., Siedlecki W. (red.), Kodeks postępowania cywilnego. Komentarz, t. 2, Warszawa 1976.

Rzewuska M., Skuteczność egzekwowania świadczeń alimentacyjnych należnych małoletnim od dłużników ukrywających się za granica, Palestra 2011, nr 11-12.

Siwiec K., Eksmisja na nowych zasadach, Nieruchomości 2014, nr 6.

Szczurek Z. (w:) Egzekucja sądowa w Polsce, red. Z. Szczurek, Sopot 2007.

Szczurek Z., Wiedza o majątku dłużnika środkiem efektywnego - szybkiego i skutecznego zaspokojenia praw wierzyciela w postępowaniu egzekucyjnym, Gdańskie Studia Prawnicze 2009, t. 21.

Wengerek E., Sądowe postępowanie egzekucyjne w sprawach cywilnych, Warszawa 1978.

Wróbel A., Autonomia proceduralna państw członkowskich.Zasada efektywnościoraz efektywnejochrony sądowejw prawie Unii Europejskiej, Ruch Prawniczy, Ekonomiczny i Socjologiczny 2005, tom VXII, z. 1.

Zedler F., Sądowe postępowanie egzekucyjne w orzecznictwie Trybunału Konstytucyjnego w latach 1985-2008 (w:) Orzecznictwo Trybunału Konstytucyjnego a kodeks postępowania cywilnego, red. T. Ereciński, K. Weitz, Warszawa 2010.

Zedler F., Glosa do uchwały SN z dnia 20 czerwca 2000 r., III CZP 16/00, OSP 2001, z. 9, poz. 133.

\section{Wykaz orzecznictwa:}

wyrok ETPC z dnia 28 lipca 1999 r. w sprawie Immobiliare Saffi przeciwko Włochom, skarga nr 22774/93;

wyrok ETPC z dnia 19 marca 1997 r. w sprawie Hornsby przeciwko Grecji, skarga nr 18357/91;

wyrok ETPC z dnia 20 lipca 2000 r. w sprawie Antonetto przeciwko Włochom, skarga nr 15918/89;

wyrok ETPC z dnia 12 października 2006 r. w sprawie Orha przeciwko Rumunii, skarga nr 1486/02;

wyrok ETPC z dnia 23 września 2008 r. w sprawie Samoilă i inni przeciwko Rumunii, skarga nr 14073/03;

wyrok ETPC z dnia 15 czerwca 2006 r. w sprawie Kazmina przeciwko Rosji, skarga nr 72374/01;

wyrok ETPC z dnia 24 czerwca 2008 r. w sprawie Cone przeciwko Rumunii, skarga nr 35935/02;

decyzja ETPC z dnia 22 lutego 2011 r. w sprawie Gaftoniuc przeciwko Rumunii, skarga nr 30934/05;

wyrok ETPC z dnia 15 stycznia 2009 r. w sprawie Burdov przeciwko Rosji nr 2, skarga nr 33509/04; wyrok ETPC z dnia 7 czerwca 2011 r. w sprawie Güler i Kekeç przeciwko Turcji, skarga nr 33994/06; decyzja ETPC z dnia 24 listopada 2005 r. w sprawie Immobiliare Saffi S.R.L. przeciwko Włochom, skarga nr 22774/93;

wyrok ETPC z dnia 7 czerwca 2005 r. w sprawie Fuklev przeciwko Ukrainie, skarga nr 71186/01; wyrok ETPC z dnia 14 września 2010 r. w sprawie Chiş przeciwko Rumunii, skarga nr 3360/03; wyrok ETPC z dnia 9 grudnia 2008 r. w sprawie Ciocan przeciwko Rumunii, skarga nr 6580/03; wyrok ETPC z dnia 1 kwietnia 2010 r. w sprawie Margushin przeciwko Rosji, skarga nr 11989/03; wyrok ETPC z dnia 19 stycznia 2010 r. w sprawie Voda przeciwko Rumunii, skarga nr 35812/02; wyrok ETPC z dnia 19 grudnia 2002 r. w sprawie Paola Esposito przeciwko Włochom, skarga nr 30883/96;

wyrok ETPC z dnia 24 maja 2007 r. w sprawie Tuleshov przeciwko Rosji, skarga nr 32718/02;

wyrok ETPC z dnia 9 października 2007 r. w sprawie Stanková przeciwko Słowacji, skarga nr 7205/02; wyrok ETPC z dnia 15 stycznia 2009 r. w sprawie Ćosić przeciwko Chorwacji, skarga nr 28261/06; wyrok TK z dnia 19 lutego 2008 r., P 49/06, OTK-ZU 2008, nr 1, poz. 5; wyrok TK z dnia 24 lutego 2003 r., K 28/02, OTK-A 2003, nr 2, poz. 13; wyrok TK z dnia 4 listopada 2010 r., K 19/06, OTK-A 2010, nr 9, poz. 9; wyrok TK z dnia 4 kwietnia 2001 r., K 11/00, OTK 2001, nr 3, poz. 54; wyrok TK z dnia 27 maja 2008 r., P 59/07, OTK-A 2008, nr 4, poz. 64. 


\section{Wykaz aktów prawnych:}

Karta Praw Podstawowych Unii Europejskiej, Dz.Urz. UE C Nr 326.

Konwencja o Ochronie Praw Człowieka i Podstawowych Wolności sporządzona w Rzymie dnia 4 listopada 1950 r., zmieniona następnie Protokołami nr 3, 5 i 8 oraz uzupełniona Protokołem nr 2, Dz.U. z 1993 r. Nr 61, poz. 284.

Ustawa z dnia 29 sierpnia 1997 r. o komornikach sądowych i egzekucji, t.j. Dz.U. z 2016 r., poz. 1138 ze zm.

Ustawa z dnia 16 września 2011 r. o zmianie ustawy - Kodeks postępowania cywilnego oraz niektórych innych ustaw, Dz.U. Nr 233, poz. 1381.

Rozporządzenie Prezydenta RP z dnia 29 listopada 1930 r. - Kodeks postępowania cywilnego, Dz.U. z 1930 r. Nr 83, poz. 651. Akt uchylony z dniem 1 stycznia 1965 r.

Ustawa z dnia 21 czerwca 2001 r. o ochronie praw lokatorów, mieszkaniowym zasobie gminy i o zmianie Kodeksu cywilnego, Dz.U. z 2016 r., poz. 1610.

\section{Streszczenie}

Zasada efektywnej ochrony sądowej stanowi element unijnego porządku prawnego, systemu konwencyjnego oraz występuje w systemach krajowych. Podstawowym elementem skutecznej ochrony prawnej jest prawo do sądu (art. 47 zd. 1 Karty Praw Podstawowych Unii Europejskiej, art. 6 ust. 1 Konwencji o Ochronie Praw Człowieka i Podstawowych Wolności). Zasada sprawnej egzekucji stanowi istotę prawa do sądu. Sprawna egzekucja sprzyja pogłębianiu zaufania obywateli do organów wymiaru sprawiedliwości. Zdaniem Trybunału Konstytucyjnego wykonanie orzeczenia jest integralną częścią procesu. Postępowanie rozpoznawcze stanowi tzw. „fazę wstępną”, zaś egzekucja służy właściwej realizacji efektywnej ochrony sądowej. Postępowanie egzekucyjne służy zaspokojeniu roszczeń wierzyciela, których nie udało mu się uzyskać dobrowolnie. Zasada sprawnej egzekucji w pełni realizuje interes wierzyciela, nie zaś dłużnika. Egzekucja sądowa, stanowiąca istotę postępowania egzekucyjnego, powinna przebiegać w sposób sprawny i szybki. Sprawność egzekucji gwarantują stosowane przez organy egzekucyjne, tj. komornika oraz sąd, środki przymusu przewidziane w ustawie procesowej.

Zasada prawa do sądu (art. 45 ust. 1 Konstytucji RP) oraz zasada demokratycznego państwa prawnego (art. 2 Konstytucji RP) chronią egzekucję prawomocnych wyroków. Postępowanie egzekucyjne wyróżnia działanie dwóch naczelnych zasad postępowania cywilnego, tj. zasady formalizmu oraz dyspozycyjności.

Słowa kluczowe: egzekucja sądowa, przewlekłość postępowania, zasada dyspozycyjności, zasada formalizmu, prawo do sądu.

\section{The principle of efficient court enforcement as an element of effective execution of justice}

\section{Summary}

The principle of effective judicial protection constitutes an element of the EU law, the Convention system and is found in national systems. The right to a court is a fundamental element of effective legal protection (Article 47/1 of the Charter of Fundamental Rights of the European Union, Article 6, Paragraph 1 of the Convention for the Protection of Human Rights and Fundamental Freedoms). The 
principle of effective enforcement is the essence of the right to a court. Efficient execution enhances citizens' confidence in the law. According to the Constitutional Court, the execution of a court ruling is an integral part of the trial. Examination proceedings constitute the so-called "preliminary stage", and the execution serves the proper implementation of effective judicial protection. Enforcement proceedings serve the fulfillment of the creditor's claims, which he has not been able to obtain on a voluntary basis. The principle of effective enforcement fully serves the interests of the creditor, not the debtor. Court enforcement, which is the essence of enforcement proceedings, should be conducted in a fast and efficient manner. The efficiency of enforcement is ensured by enforcement bodies, i.e. bailiffs and courts, coercive measures provided for by the law of civil procedure. The principle of the right to a court (Article 45, Paragraph 1 of the Constitution of the Republic of Poland) and the principle of democratic rule of law (Article 2 of the Constitution of the Republic of Poland) protect the execution of final judgments. Enforcement proceedings is distinguished by the operation of two main principles of civil proceedings, i.e. the principle of formalism and availability.

Key words: court enforcement, excessive length of proceedings, principle of availability, the principle of formalism, the right to a court. 